\title{
Climate change affects seed aging? Initiation mechanism and consequences of loss of forest tree seed viability
}

\author{
Joanna Kijowska-Oberc ${ }^{1} \mathbb{D} \cdot$ Aleksandra M. Staszak $^{2} \cdot$ Ewelina Ratajczak $^{1}$
}

Received: 12 June 2020 / Accepted: 17 December 2020 / Published online: 7 January 2021

(c) The Author(s) 2021

\begin{abstract}
Key message Environmental stress resulting from rapid climate changes leads to the initiation of the seed aging process in mitochondria and peroxisomes. Seed storage methods limiting germinability loss are fundamental for forest future.

Abstract Seed aging is a natural process. It decreases the seed germination rate, i.e. the process is essential for the plant's life cycle. Aging involves a progressive accumulation of oxidative damage over time. One of the main plant responses to stress is an excessive production of reactive oxygen species (ROS), such as $\mathrm{O}_{2}^{-\bullet}, \mathrm{H}_{2} \mathrm{O}_{2}$ and ${ }^{\bullet} \mathrm{OH}$. If the concentration of ROS is too high, it causes damage of the structure of lipid membranes, proteins, carbohydrates, and DNA. Climate changes affect tree reproduction and may have long-term consequences in the form of reduced species dispersal and acquisition of new habitats. High temperatures accelerate the aging of seeds and decrease their viability. There is, therefore, an indisputable need to store forest reproductive material to maintain continuity of regeneration in farm forests. The quality of seeds subjected to longterm storage correlates negatively with ROS concentration, as ROS accumulation typically occurs in tissues experiencing oxidative stress. Therefore, to preserve forest genetic resources, it is particularly important to know the causes and sites of initiation of the aging process in seed cells, as well as to prevent the germination rate decrease by developing appropriate storage methods. The main organelles responsible for intracellular ROS production are mitochondria and peroxisomes. This article aims at verifying the causes of seed aging and determining its consequences for future forest regeneration due to climate changes. We review the literature on oxidative stress, as well as the sites where the tree seed aging process originates, such as mitochondria and peroxisomes.
\end{abstract}

Keywords Seeds aging $\cdot$ Climate change $\cdot$ Reactive oxygen species $\cdot$ Antioxidants system $\cdot$ Mitochondria $\cdot$ Peroxisomes

\section{Introduction}

The seed is the first developmental phase and the basic form of adaptation of higher plants to surviving in unfavorable environmental conditions. It is the role of seeds to transfer features to offspring, in other words, to guarantee the continuity of species (Kurek et al. 2019). Seeds tend to age, just like any other plant organ (Lehner et al. 2008). The process

Communicated by M. Buckeridge.

Joanna Kijowska-Oberc

joberc@man.poznan.pl

1 Institute of Dendrology, Polish Academy of Sciences, ul. Parkowa 5, 62-035 Kórnik, Poland

2 Faculty of Biology, University of Bialystok, ul. Ciołkowskiego 1J, 15-245 Białystok, Poland reduces plant's ability to germinate, which is the essential role of seeds in the life cycle of plants (Jiménez-Alfaro et al. 2016). The viability of seeds is modified by various factors like: (1) internal physiological and biochemical (Hu et al. 2012a) that depend on the species and are genetically conditioned (Becerra-Vázquez et al. 2018), and (2) external, such as moisture and temperature conditions of storage of seeding material (Pukacka and Ratajczak 2007). In the "free-radical theory" of aging, Harman (2006) assumed that aging is a progressive process of the accumulation of oxidative damage, induced by oxidative stresses of various origins that gradually increase the risk of death of all living organisms.

Throughout their long lives, trees are exposed to various kinds of stress (Kijowska-Oberc et al. 2020). It may be caused by unfavorable external conditions, such as water shortage, extreme temperatures, strong salinity or too high levels of toxic metals (Siripornadulsil et al. 2002). 
Depending on the inducing factor, stress may restrain plant development to a different degree at the various phases of its life (Hayat et al., 2012). One of the main responses of plants to stress is an excessive production of reactive oxygen species (ROS), such as $\mathrm{O}_{2}^{-\bullet}, \mathrm{H}_{2} \mathrm{O}_{2}$ and ${ }^{\bullet} \mathrm{OH}$ (Das and Roychoudhury 2014; Kurek et al. 2019; Huang et al. 2019). High concentrations of ROS cause damage by inactivating enzymes, disturbing the structure of lipid membranes, proteins carbohydrates and DNA (Sharma et al. 2012; Silva et al. 2018).

Climate change, which affects the reproduction of trees, may have long-term consequences by reducing species dispersal and by the acquisition of new habitats (Dyderski et al. 2018; Wang et al. 2019; Bogdziewicz et al. 2020). Therefore, there is an indisputable need to store forest reproduction material to guarantee the continuity of regeneration of species in farm forests. Trees produce more flowers at higher temperatures but the flowers are not effectively pollinated and numerous seeds are infertile as a result (Pearse et al. 2016). Global warming influence on the reproductive effort of forest trees, that display masting - the synchronized production of large amounts of seeds, but the specific impact is still difficult to assess (Caignard et al. 2017). High temperatures of air are recognized by trees as a signal to get ready to produce more seeds; this is termed the "seeding year" (Koenig et al. 2016). On the other hand, heavy-seed species need a couple of years to recover the energy, indispensable for producing flowers and fruit in high numbers again, and this results in desynchronized seed yields (Monks et al. 2016). Observations conduced in the recent decades revealed a relationship between the increase in average temperatures and higher frequency of seeding years in European beech (Fagus sylvatica L.) (Bogdziewicz et al. 2020), temperate oaks (sessile oak-Quercus petraea (Matt.) Liebl. and pedunculated oak-Quercus robur L.) (Caignard et al. 2017).

Most species have clearly recalcitrant or orthodox seeds. However some species with recalcitrant seeds can significantly change their position on the desiccation tolerance scale depending on climate (Daws et al. 2006). Climate changes occur at a rate that is too fast to enable genetic adaptation of such species, and thus these plants may have a considerable influence on the ability of their seeds to germinate (St Clair and Lynch 2005). Desiccation tolerance, such as other plant features, is shaped under the environmental conditions by phenotypic plasticity (Fang et al. 2017; Solarik et al. 2018) and it may affect the limits of species natural ranges (Dobrowolska 2015; Cavin and Jump 2017). Daws et al. (2006) proved that recalcitrant seeds of sycamore (Acer pseudoplatanus L.) can move from one seed storage category to the next under the impact of climate changes. They showed that seedlings from warmer locations in Europe (France and Italy) were more desiccation tolerant than those from cooler locations (Norway and Scotland), therefore environmental conditions during seed development systematically affect seed features including the level of seed desiccation tolerance. Those observations have supported the work of Walters et al. (2005), who found that seeds from warm, arid environments have the ability to withstand longterm storage in contrast to seeds derived from temperate and moist regions.

Research of Pukacka et al. (2003) indicate that the reduced viability of the seeds of European beech after being stored for 10 years correlated positively with increased concentrations of ROS and lipid peroxidation products, the accumulation of which is typically observed in tissues under oxidative stress conditions. During the long-term storage, the redox state in cells of beech seeds significantly changes and it may resulting in intensifying the process of aging, which leads to the reduction of seed viability (Ratajczak et al. 2019c). Maintenance of the redox status balance in cells of seeds has a considerable impact on the preservation of seed viability during drying and storage (Ratajczak et al. 2019a). Reproduction plays the key role in populations survival, thus it should be taken into consideration during modeling responses of populations to climate change (Morin et al. 2008; Dyderski et al. 2018). Therefore, for the preservation of the gene resources of forests, it is of particular importance to understand the causes of aging and the sites of its initiation within seed cells, as well as to prevent the loss of germination by developing appropriate seed storage methods.

Mitochondria and peroxisomes are the main organelles responsible for the intracellular production of reactive oxygen species (Cabiscol et al. 2013; Liberatore et al. 2016; Ratajczak et al. 2019b). One of the sources of ROS is the mitochondrial electron transport chain that generates $\mathrm{O}_{2}^{-\bullet}$. Plant peroxisomes produce mainly $\mathrm{H}_{2} \mathrm{O}_{2}$ (Luis et al. 2006). In this paper, we attempted to identify the causes of seed aging and the consequences of climate change with reference to guaranteeing the appropriate seeding reserves for the purpose of forest regeneration in the future. With this in mind, we made a survey of the literature on oxidative stress as well as the sites where seed aging is initiated, such as the mitochondria and peroxisomes, in the seeds of trees.

\section{Reactive oxygen species vs. sensitivity of plants to stress}

The extent of seed damage during storage depends on their specific characteristics and requirements (Walters et al. 2005; Rajjou et al. 2008; Sano et al. 2016). Drought is a stress factor reducing metabolic activity, but reduced water content is required et several phases of the development, such as seed desiccation (Leprince et al. 1999). Based on 
these, seeds are classified into three categories: orthodox, recalcitrant and intermediate. Orthodox seeds acquire desiccation tolerance, therefore they are prepared for survival in unfavorable environmental conditions even during development. This adaptive strategy is a result of sugar, heat shock proteins (HSPs) and late embryogenesis abundant proteins (LEAs) syntheses (Berjak et al. 2007). However, recalcitrant seeds cells do not contain those components and the lack of them leads to membrane damage and, as a consequence, to viability loss due to environmental stress (Black et al. 2006). Recalcitrant seed may lose viability during long-term storage because of water content remaining high during their development until germination (Walters 2015).

Under favorable conditions ROS levels are effectively controlled. They occur as regulators in process of cell growth and development of tissues, in photosynthesis, respiration and cell cycle (Buetler et al. 2004). Stress factors disturb redox homeostasis, resulting in excessive accumulation and decreased elimination of ROS, which leads to the oxidative stress state (Noctor et al. 2018). The oxidative stress occurring in seed cells contributes to deterioration of the seeding material. This state is generated by disturbances of an equilibrium of the system protecting the cells from excess ROS (Demidchik 2015; Huang et al. 2019). The ROS comprise superoxide anion radical $\mathrm{O}_{2}^{-\bullet}$ and hydrogen peroxide $\mathrm{H}_{2} \mathrm{O}_{2}$, as well as free radicals (oxygen-based and organic), including highly reactive hydroxyl radical $\bullet \mathrm{OH}$ (Kumar et al. 2015). These molecules contain unpaired electrons and react readily with proteins, lipids and nucleic acids. The hydroxyl radical $\bullet \mathrm{OH}$ is the most aggressive form of ROS: it causes structural damage in deoxyribose, pyrimidines and purines (Cadet et al. 2017). The concentration of ROS varies during the whole life of seeds. During the development of Norway maple seeds, $\mathrm{H}_{2} \mathrm{O}_{2}$ potentially plays a signaling role in acquisition of desiccation tolerance (Ratajczak et al. 2019a). Orthodox seeds of this species acquire water stress tolerance as a result of intracellular modifications, e.g. accumulation of lipids and starches, the presence of heat shock proteins (HSPs) and late embryogenesis abundant proteins (LEAs), improving cell mechanical resilience and facilitating storage in a dry state conditions (Waterworth et al. 2015; Kubala et al. 2015). The reason why the recalcitrant and the intermediate seeds are less viable after being desiccated and stored is that ROS are produced in excess in response to the stressful conditions. Furthermore, they are accumulated and not removed as effectively as in orthodox seeds, because of lower activity of several elements of the antioxidant system, such as glutathione (GSH), ascorbate (ASC) (Ratajczak et al. 2015) or LEAs, which have been shown to be critical for desiccation tolerance (Delahaie et al. 2013).

During storage, the level of ROS in the seeds will grow, affecting their viability and germination ability (Bailly and Kranner 2011; Parkhey et al. 2012; Gomes and Garcia 2013;
Jeevan Kumar et al. 2015). This happens because the ROS cause a number of unfavorable changes in the cells which, in turn, affect the quality of seeds during storage and their viability (Fig. 1). Peroxidation (1), i.e., oxidation of lipids, is one of the main causes of deterioration of the seeding material (Parkhey et al. 2012). The process affects the components of the cell membranes, disturbing their selective permeability (Ratajczak et al. 2015). It also disturbs the performance of the antioxidant system enzymes (Pukacka and Ratajczak 2007). Carbonylation of proteins (2), during which carbonyl groups are formed in the radicals of some amino acids, may result in modified conformations, followed by changes in or loss of some of the functions of the proteins (Dalle-Donne et al. 2003; Kalemba and Pukacka 2014). The number of cracks in the DNA helix or single thread grows higher with the seed age and the associated increase in ROS concentration (3), often leading to chromosomal aberrations (Waterworth et al. 2015). Moreover, malonaldehyde - the product of a reaction between oxygen radicals and the cell membrane lipids - may react with nitrogen bases of DNA (Marnett 1999; Grotto et al. 2009). All these processes decrease the seed viability.

\section{Antioxidant system in seed cells}

The extent of damage taking place in the seed cells is correlated with the efficiency of the enzymatic and non-enzymatic elements of their antioxidant systems (Bailly 2004). The function of these systems is to eliminate oxidative agents, but also to maintain redox equilibrium (Foyer and Noctor 2005; Dietz and Hell 2015; Noctor et al. 2018).

The enzyme-based antioxidant system comprises a number of enzymes: superoxide dismutases (SOD), peroxidases (POX), catalase (CAT), ascorbate-glutathione cycle enzymes, and proteins comprising thiol groups such as peroxyredoxins (Prxs) (Fig. 1). The superoxide dismutase neutralizes the superoxide anion radical $\mathrm{O}^{-\bullet}$ to hydrogen peroxide $\mathrm{H}_{2} \mathrm{O}_{2}$ and oxygen (Wang et al. 2018). Catalase (CAT) neutralizes hydrogen peroxide (Apel and Hirt 2004) and is present mainly in peroxisomes and glyoxysomes (Ighodaro and Akinloye 2017). CAT is a verified indicator of improvement of the seed quality and germination ability (Kibinza et al. 2011). Plant cells commonly comprise the glutathione, guaiacol and ascorbate peroxidases that catalyze the decomposition of hydrogen peroxide. Oxidative damage of cells is also prevented by the alternative peroxidase (AOX) (Selinski et al. 2018). PRXs mentioned above are enzymes that neutralize hydrogen peroxide (Foyer and Noctor 2005). They have a number of important functions, for instance, they control cell signals and the redox condition in plant cells. This way, peroxyredoxins help plants adapt to new environmental conditions (Dietz 2011; Liebthal et al. 2018). Their application may improve the seed tolerance 


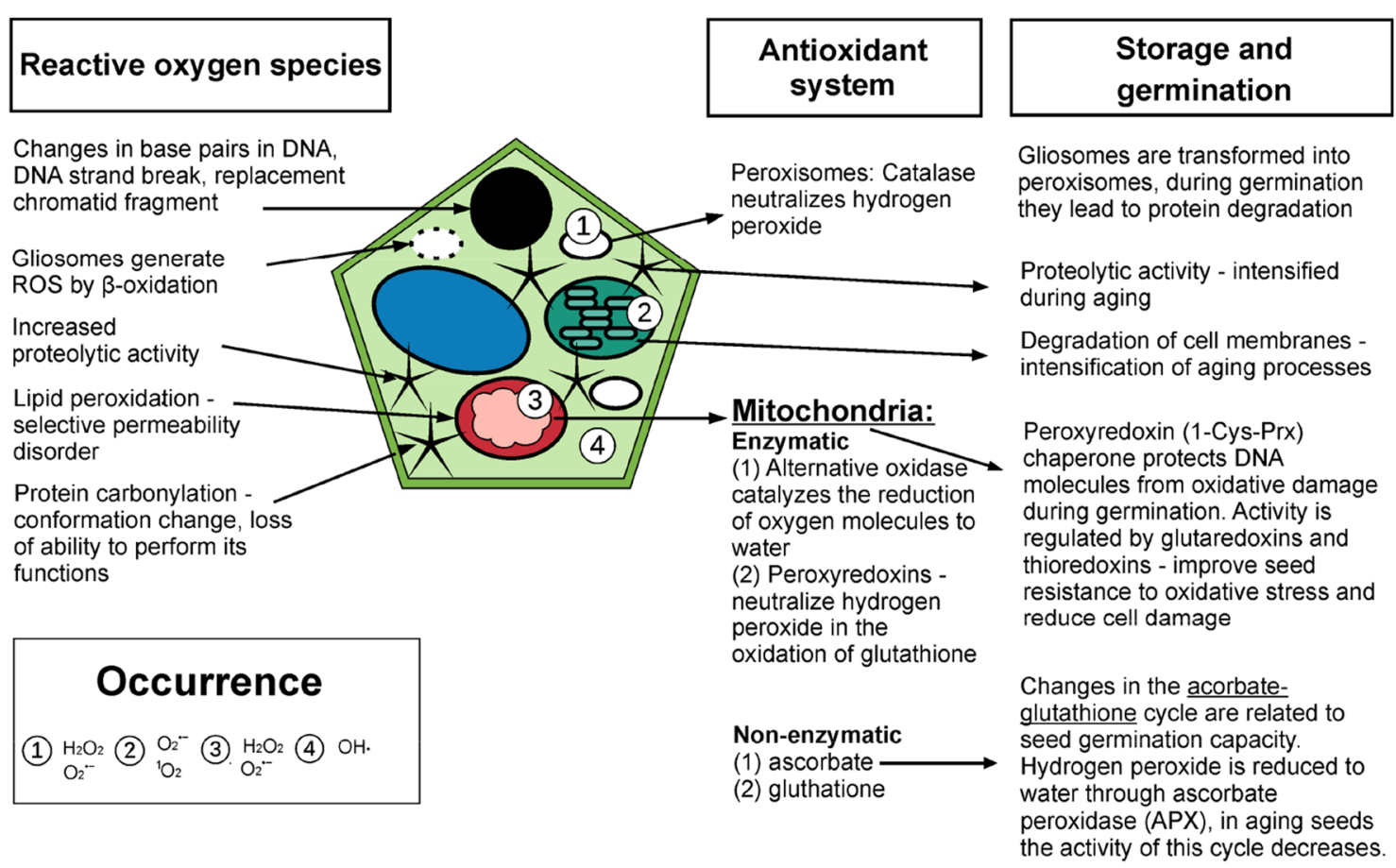

Fig. 1 The activity of reactive oxygen species and components of the antioxidant system affecting seeds quality during long-term storage and seed germination in plant cell

to oxidative stress and diminish cell damage (El-MaaroufBouteau and Bailly 2008; Xie et al. 2019).

The non-enzymatic components of the antioxidant system include low molecular compounds: ascorbic acid (its reduced form ASA and oxidized form DHA), and glutathione (its reduced form GSH and oxidized form GSSG) (Mittler et al. 2004; Kranner et al. 2006; Xia et al. 2015). These low molecular antioxidants cooperate in the Halliwell-Asada cycle (ascorbate-glutathione cycle, ASC-GHS cycle), and changes in its activity affect seed germination (Fig. 1) (Pukacka and Ratajczak 2007). In the seeds of European common beech after aging, the concentration of ASA in samples stored for 2 years decreased twice as much as that in the seeds stored for 5 years, and the level of GSSG was higher than that of GSH, indicating the oxidative stress condition in the seeds. This means a positive correlation between germination and the content of ASA and GSH in the seeds (Pukacka and Ratajczak 2007).

\section{Seed aging initiation sites}

\section{Mitochondria}

The mitochondria are the essential sources of energy for cell growth and metabolic activity. Being one of the main sites of ROS production, these organelles are also responsible for maintaining cell redox equilibrium (Ratajczak et al. 2019b). The mitochondrial ROS are mainly generated in complex I and complex III of the mitochondrial electron transport chain (Barranco-Medina et al. 2007; Robb et al. 2018), from which $\mathrm{O}_{2}^{-\bullet}$ molecules are released into the matrix, and in complex II during the reverse transport of electrons to complex I (Blokhina and Fagerstedt 2010). Decomposition of $\mathrm{O}_{2}^{-\bullet}$ produces $\mathrm{H}_{2} \mathrm{O}_{2}$, which has the ability to freely pass through the cell membranes. It reacts with $\mathrm{O}_{2}^{-\bullet}$ generating a highly reactive ${ }^{\bullet} \mathrm{OH}$, and its reaction with $\mathrm{NO}$ produces the powerful oxidant $\mathrm{ONOO}^{-}$(Belhadj Slimen et al. 2014). The mitochondria comprise proteins which take part in the formation of ROS such as glycerophosphate dehydrogenase (Drahota et al. 2002, Murphy 2009), pyruvate dehydrogenase complex with many subunits, as well as the structurally membrane-bound complex of $\alpha$-ketoglutarate dehydrogenase (Starkov et al. 2004).

ROS disturb the integrity of membranes and other cell components (Dunn et al. 2015). Under oxidative stress, the activity of mitochondrial proteins is reduced due to binding the lipid peroxidation products (Winger et al. 2007), the formation of carbonyl groups (Kristensen et al. 2004) and oxidation of tryptophan radicals (Møller and Kristensen 2004). In the seeds of trees of the genus elm (Ulmus L.), 48 mitochondrial proteins were transformed during aging and it was confirmed that these changes were linked to the mitochondrial electron transport chain and to the Krebs 
cycle (TCA) - the basic path of aerobic respiration (Li et al. 2017). Oxidative phosphorylation is one of the main sources of ROS in cells. Combined with the "free-radical theory" (Harman 2006), which describes aging as an accumulation of free radicals, it gives grounds for believing the theory correctly describes mitochondria as the seed aging initiation sites (Ratajczak et al. 2019b).

Seed aging has a direct impact on the effectiveness of the electron transport chains by reducing ATP production. Therefore, the aging seed cells are not capable of releasing enough energy stored in ATP to initiate germination. Stress in the mitochondria triggers energy deficit signals (Liberatore et al. 2016) in the form of changes in the ROS level and the mitochondrial redox condition, which in turn affect the expression of mitochondrial and nuclear genes controlling seed aging (Yin et al. 2016). Changes in the mitochondrial redox condition control not only the mitochondrial activity but also various processes taking place in the cells, such as seed germination (Nietzel et al. 2020) or activation of apoptosis (programmable cell death) (Rouhier and Jacquot 2005).

\section{Peroxisomes}

Peroxisomes are eukaryotic organelles in which $\mathrm{H}_{2} \mathrm{O}_{2}$ production and decomposition take place. These molecules are neutralized by CAT, called the marker protein for peroxisomes, in which the enzyme constitutes up to $25 \%$ of total protein content (Corpas et al. 2001). In this way, these organelles help control the redox condition in addition to being important generators of molecular signals (Corpas et al. 2001). In photosynthesizing tissues, the essential task of peroxisomes is their role in photorespiration ( $\mathrm{Hu}$ et al. 2012b). On the other hand, glyoxysomes - the category of peroxisomes that are present in seeds-take part in ROS production by $\beta$-oxidation of lipids. This is a process that enables the mobilization of storage material in the form of lipids, which are accumulated in the endosperm during the seed maturation. After being transformed into sugars, the lipids are oxidized, generating metabolically useful energy (Graham 2008). Moreover, germination inhibitors may become neutralized during $\beta$-oxidation, which interrupts the seed dormancy phase (Footitt et al. 2006).

The seed aging process is accompanied not only by enhanced lipid peroxidation but also by an increase in proteolytic activity (Distefano et al. 1999). Proteolysis is the process in which peptide bonds are disrupted by proteases. It helps maintain an equilibrium between the biosynthesis and the elimination of the exhausted cell components (Hu et al. 2012b). Proteolysis is indispensable during germination, morphogenesis and apoptosis (Palma et al. 2002). The process is related to oxidative stress: the rate of proteolysis is higher in cells exposed to stressogenic factors (Pyngrope et al. 2013) because intracellular proteins, damaged by ROS molecules, are identified and selectively decomposed by endopeptidases (Grune et al. 1997). Proteolytic activity was observed also in the peroxisomes. The transformation of glyoxysomes into leaf peroxisomes during germination as well as the reverse process implies the degradation of previously existing proteins in these organelles (Nishimura et al. 1996).

\section{Summary: global warming vs. the quality of the seeding material}

The frequency of extreme weather conditions, such as hurricanes but also droughts and heat waves (Easterling et al. 2000) grows as the result of high atmospheric $\mathrm{CO}_{2}$ levels, among other things. In 2015, $\mathrm{CO}_{2}$ level exceeded $400 \mathrm{ppm}$ for the first time since its monitoring has begun (Jones 2017). Climate conditions changes in recent years are noticeable (Fig. 2) and they have an impact on seeds, contributing directly and indirectly to deterioration of their quality, vitality and quantity. High air temperature in the year predicting the "seeding year" is recognized by trees as a signal to abundant flowering and high seed production next season (Koenig et al. 2016). However the improving performance of trees during the increase of mean air temperature is only an apparent phenomenon, because increased seed production is accompanied by a decrease in the synchrony of reproduction (Bogdziewicz et al. 2020). It is a result of the need for several years of energy regeneration necessary to produce such a large number of reproductive organs and fruits (Monks et al. 2016).

Stress, the plant response to unfavorable environmental conditions, makes the plants produce too much ROS. As the result of excess ROS, the plant DNA and proteins are damaged, which disturbs the seed maturation process. In effect, seed aging is induced too early for them to maintain their high quality and enable the desirable breeding effects to be obtained in the future (Fig. 3). In 2018, an experiment was carried out in which individuals representing 17 tree species were made to germinate and grow at controlled conditions, at temperatures and $\mathrm{CO}_{2}$ levels above natural (Kim and Han 2018). The experiment proved that long-term exposure of seeds to high temperatures not only affected their ability to germinate but also disturbed their dormancy, resulting in reduced activity of hormones and enzymes, and all this induced germination. In another study extensive sets of tree reproduction data for sessile oak and the pedunculate oak was analyzed to determine whether seed production had changed over the last two decades in response to global warming. Monitoring of seed production was carried out for 14 years in 28 forests of both tree species distributed throughout France. These analyses showed significant 
Fig. 2 Changes in the maximum, minimum and mean temperatures, and mean precipitation in subsequent months in 2016, 2017, 2018 and 2019 seasons in Kórnik, Poland (data from meteo station)
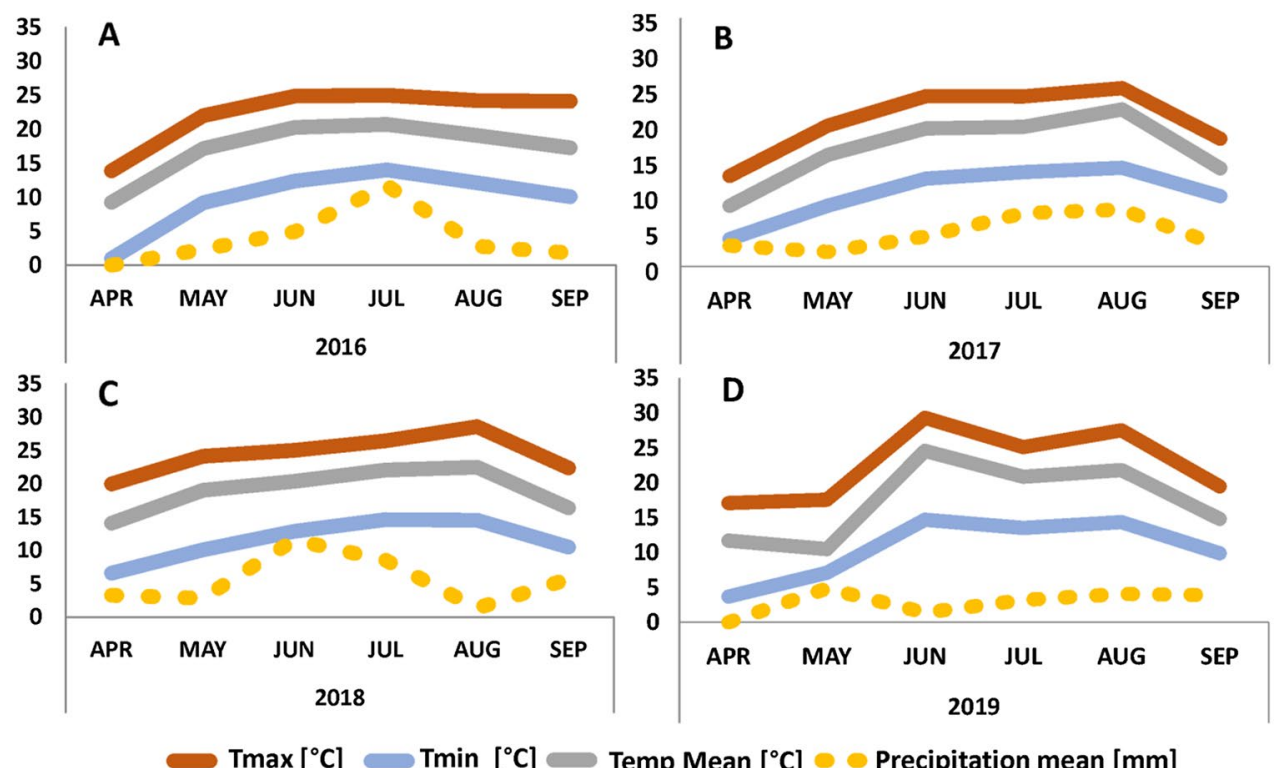

2019

Temp Mean $\left[{ }^{\circ} \mathrm{C}\right] \odot$ Precipitation mean [mm]
Fig. 3 Impact of changing climatic conditions on the quality and viability of forest reproductive material, current knowledge and perspectives
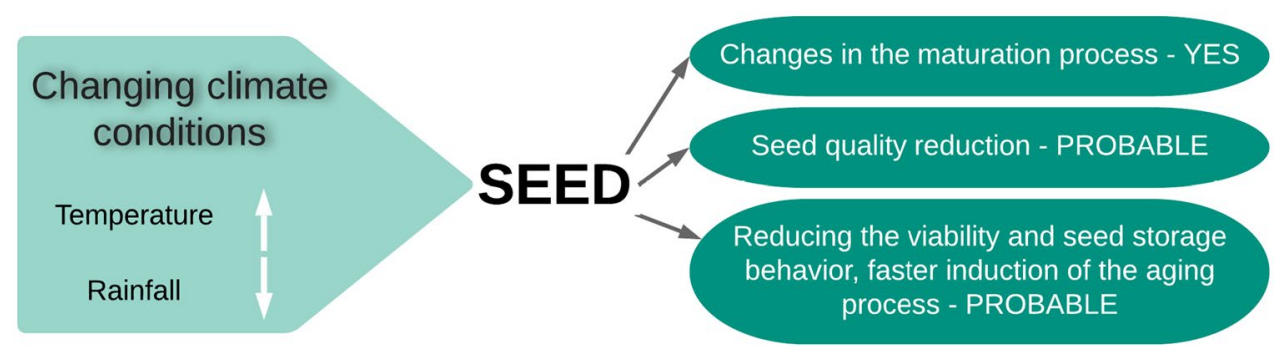

temperature-induced trends in seed production (Caignard et al. 2017).

Desiccation tolerance may be a hereditary trait while desiccation sensitivity is environmentally determined (Dickie and Pritchard 2002; Oliver et al. 2000). Therefore the loss of desiccation tolerance results vitality predominance, as desiccation-sensitive species, contrary to species with high desiccation tolerance, directly commit fewer resources to mitigate seed predation by faster germination. In dryland habitats with sporadic rainfall they have a number of adaptations that reduce the loss of seed viability and maintain their high quality. In these species, shedding occurs at the time of maximum annual rainfall (1), they produce seeds of large weight (2) to reduce the rate of seed drying and they are also characterized by rapid germination (3), which allows them to reduce seed dehydration (Pritchard et al. 2004). Desiccation sensitivity and other traits of specific species may form a continuum of responses in relation to maturation status (Daws et al. 2004). For instance, sycamore (Acer pseudoplatanus L.) seeds can shift their seed storage category depending on climate (Daws et al. 2006), while seeds of Trichilia emetica Vahl., tropical African forest species, tolerate elevated temperature or even such thermal conditions may to increase germinability (Sershen et al.2014). Environmental conditions during seed development affect the seed features such as their level of desiccation tolerance. For example, a promising indicator of oxidative stress levels changing due to thermal or drought stress may be proline, which reaches higher levels in more sensitive to environmental stress, recalcitrant seeds (Kijowska-Oberc et al.- research under revision). For this reason, it is important to take into consideration the species provenance during the characterization of seed desiccation tolerance and other responses.

The indirect effect of global warming on seeds is connected with their long-term storage. Desynchronization of massive seed yields for trees exhibiting cyclic yields results in a lower number of seeds with a living embryo (Bogdziewicz et al. 2020). Under the circumstances, it becomes indispensable to secure the seeding material by storing it after harvesting for the purpose of forest regeneration in the future. However, seeds with lower tolerance affected by high temperatures and water deficit in the maturation phase may rapidly loose viability during long-term storage (Fig. 3). Understanding how those changes affect seed quality and desiccation tolerance may be crucial for protecting the genetic resources of forest species. Meanwhile, research 
on the impact of climate change on the aging process of seeds usually concerns herbs (Davies et al. 2013; Willis et al. 2008), rather than woody plants. Minimization of the risk of seed aging initiation will help maintain their quality and viability. Germination ability is a fundamental value in forest cultivation as it ensures the continuity of forest ecosystems.

Author contribution statement Conceptualization, ER and JKO; writing-original draft preparation, JKO and ER; writing — review and editing, JKO, ER, AMS; visualization, JKO, ER, AMS; supervision ER; funding acquisition, ER. All authors have read and agreed to the published version of the manuscript.

Funding This research was supported by the National Centre of Sciences (Grant number 2018/31/B/NZ9/01548). Additional funding was provided by the Institute of Dendrology, Polish Academy of Sciences.

\section{Compliance with ethical standards}

Conflict of interest The authors declare no conflict of interest.

Open Access This article is licensed under a Creative Commons Attribution 4.0 International License, which permits use, sharing, adaptation, distribution and reproduction in any medium or format, as long as you give appropriate credit to the original author(s) and the source, provide a link to the Creative Commons licence, and indicate if changes were made. The images or other third party material in this article are included in the article's Creative Commons licence, unless indicated otherwise in a credit line to the material. If material is not included in the article's Creative Commons licence and your intended use is not permitted by statutory regulation or exceeds the permitted use, you will need to obtain permission directly from the copyright holder. To view a copy of this licence, visit http://creativecommons.org/licenses/by/4.0/.

\section{References}

Apel K, Hirt H (2004) Reactive oxygen species: metabolism, oxidative stress, and signal transduction. Annu Rev Plant Biol 55:373-399. https://doi.org/10.1146/annurev.arplant.55.031903.141701

Bailly C (2004) Active oxygen species and antioxidants in seed biology. Seed Sci Res 14:93-107. https://doi.org/10.1079/SSR2004159

Bailly C, Kranner I (2011) Analyses of reactive oxygen species and antioxidants in relation to seed longevity and germination. Seed dormancy. Humana Press, Totowa, pp 343-367

Barranco-Medina S, Krell T, Finkemeier I et al (2007) Biochemical and molecular characterization of the mitochondrial peroxiredoxin PsPrxII F from Pisum sativum. Plant Physiol Biochem 45:729-739. https://doi.org/10.1016/j.plaphy.2007.07.017

Becerra-Vázquez ÁG, Sánchez-Nieto S, Coates R et al (2018) Seed longevity of five tropical species from south-eastern Mexico: changes in seed germination during storage. Trop Conserv Sci 11:1940082918779489. https://doi.org/10.1177/1940082918 779489

Belhadj Slimen I, Najar T, Ghram A et al (2014) Reactive oxygen species, heat stress and oxidative-induced mitochondrial damage. A review. Int J Hypertherm 30:513-523. https://doi. org/10.3109/02656736.2014.971446
Berjak P, Farrant JM, Pammenter NW (2007) Seed desiccation-tolerance mechanisms. Plant Desicc Toler 1:151-192

Black M, Bewley JD, Halmer P (2006) The encyclopedia of seeds: science, technology and uses. Cab International, Wallington

Blokhina O, Fagerstedt KV (2010) Reactive oxygen species and nitric oxide in plant mitochondria: origin and redundant regulatory systems. Physiol Plant 138:447-462. https://doi.org/10 $.1111 / \mathrm{j} .1399-3054.2009 .01340 . x$

Bogdziewicz M, Kelly D, Thomas PA et al (2020) Climate warming disrupts mast seeding and its fitness benefits in European beech. Nat Plants. https://doi.org/10.1038/s41477-020-0592-8

Buetler TM, Krauskopf A, Ruegg UT (2004) Role of superoxide as a signaling molecule. Physiology 19(3):120-123. https://doi. org/10.1152/nips.01514.2003

Cabiscol E, Tamarit J, Ros J (2013) Protein carbonylation: proteomics, specificity and relevance to aging. Mass Spectrom Rev 33:21-48. https://doi.org/10.1002/mas.21375

Cadet J, Davies KJ, Medeiros MH, Di Mascio P, Wagner JR (2017) Formation and repair of oxidatively generated damage in cellular DNA. Free Radic Biol Med 107:13-34

Caignard T, Kremer A, Firmat C et al (2017) Increasing spring temperatures favor oak seed production in temperate areas. Sci Rep 7:8555. https://doi.org/10.1038/s41598-017-09172-7

Cavin L, Jump AS (2017) Highest drought sensitivity and lowest resistance to growth suppression are found in the range core of the tree Fagus sylvatica L. not the equatorial range edge. Glob Change Biol 23(1):362-379. https://doi.org/10.1111/gcb.13366

Corpas FJ, Barroso JB, del Río LA (2001) Peroxisomes as a source of reactive oxygen species and nitric oxide signal molecules in plant cells. Trends Plant Sci 6:145-150. https://doi. org/10.1016/S1360-1385(01)01898-2

Dalle-Donne I, Rossi R, Giustarini D et al (2003) Protein carbonyl groups as biomarkers of oxidative stress. Clin Chim Acta 329:23-38. https://doi.org/10.1016/S0009-8981(03)00003-2

Das K, Roychoudhury A (2014) Reactive oxygen species (ROS) and response of antioxidants as ROS-scavengers during environmental stress in plants. Front Environ Sci 2:53. https://doi. org/10.3389/fenvs.2014.00053

Davies TJ, Wolkovich EM, Kraft NJB et al (2013) Phylogenetic conservatism in plant phenology. J Ecol 101:1520-1530. https:// doi.org/10.1111/1365-2745.12154

Daws MI, Lydall E, Chmielarz P et al (2004) Developmental heat sum influences recalcitrant seed traits in Aesculus hippocastanum across Europe. New Phytol 162:157-166. https://doi.org /10.1111/j.1469-8137.2004.01012.x

Daws MI, Cleland H, Chmielarz P et al (2006) Variable desiccation tolerance in Acer pseudoplatanus seeds in relation to developmental conditions: a case of phenotypic recalcitrance? Funct Plant Biol 33:59-66. https://doi.org/10.1071/FP04206

Delahaie J, Hundertmark M, Bove J, Leprince O, Rogniaux H, Buitink $J$ (2013) LEA polypeptide profiling of recalcitrant and orthodox legume seeds reveals ABI3-regulated LEA protein abundance linked to desiccation tolerance. J Exp Bot 64:45594573. https://doi.org/10.1093/jxb/ert274

Demidchik V (2015) Mechanisms of oxidative stress in plants: from classical chemistry to cell biology. Environ Exp Bot 109:212-228

Dickie JB, Pritchard HW (2002) Systematic and evolutionary aspects of desiccation tolerance in seeds. Desiccation and survival in plants: drying without dying. CAB International, Wallingford, pp 239-259

Dietz K-J (2011) Peroxiredoxins in plants and cyanobacteria. Antioxid Redox Signal 15:1129-1159. https://doi.org/10.1089/ ars. 2010.3657 
Dietz KJ, Hell R (2015) Thiol switches in redox regulation of chloroplasts: balancing redox state, metabolism and oxidative stress. Biol Chem 396:483-494. https://doi.org/10.1515/hsz-2014-0281

Distefano S, Palma JM, McCarthy I, Luis A (1999) Proteolytic cleavage of plant proteins by peroxisomal endoproteases from senescent pea leaves. Planta 209:308-313. https://doi.org/10.1007/s0042 50050637

Dobrowolska D (2015) Vitality of European Beech (Fagus sylvatica L.) at the limit of its natural range in Poland. Pol J Ecol 63(2):260 272. https://doi.org/10.3161/15052249PJE2015.63.2.009

Drahota Z, Chowdhury SK, Floryk D et al (2002) Glycerophosphatedependent hydrogen peroxide production by brown adipose tissue mitochondria and its activation by ferricyanide. J Bioenerg Biomembr 34:105-113. https://doi.org/10.1023/A:1015123908 918

Dunn JD, Alvarez LA, Zhang X, Soldati T (2015) Reactive oxygen species and mitochondria: a nexus of cellular homeostasis. Redox Biol 6:472-485. https://doi.org/10.1016/j.redox.2015.09.005

Dyderski MK, Paź S, Frelich LE, Jagodziński AM (2018) How much does climate change threaten European forest tree species distributions? Glob Change Biol 24(3):1150-1163. https://doi. org/10.1111/gcb.13925

Easterling DR, Evans JL, Groisman PY et al (2000) Observed variability and trends in extreme climate events: a brief review. Bull Am Meteorol Soc 81:417-426. https://doi.org/10.1175/15200477(2000)081\%3c0417:OVATIE\%3e2.3.CO;2

El-Maarouf-Bouteau H, Bailly C (2008) Oxidative signaling in seed germination and dormancy. Plant Signal Behav 3:175-182. https ://doi.org/10.4161/psb.3.3.5539

Fang XW, Zhang JJ, Xu DH, Pang J, Gao TP, Zhang CH, Li FM, Turner NC (2017) Seed germination of Caragana species from different regions is strongly driven by environmental cues and not phylogenetic signals. Sci Rep 7(1):1. https://doi.org/10.1038/ s41598-017-11294-x

Footitt S, Marquez J et al (2006) Analysis of the role of COMATOSE and peroxisomal beta-oxidation in the determination of germination potential in Arabidopsis. J Exp Bot 57:2805-2814. https:// doi.org/10.1093/jxb/erl045

Foyer CH, Noctor G (2005) Redox homeostasis and antioxidant signaling: a metabolic interface between stress perception and physiological responses. Plant Cell 17:1866-1875. https://doi. org/10.1105/tpc.105.033589

Gomes M, Garcia Q (2013) Reactive oxygen species and seed germination. Biologia 68(3):351-357. https://doi.org/10.2478/s1175 6-013-0161-y

Graham IA (2008) Seed storage oil mobilization. Annu Rev Plant Biol 59:115-142. https://doi.org/10.1146/annurev.arplant.59.03260 7.092938

Grotto D, Maria LS, Valentini J, Paniz C, Schmitt G, Garcia SC et al (2009) Importance of the lipid peroxidation biomarkers and methodological aspects for malondialdehyde quantification. Quim Nova 32(1):169-174. https://doi.org/10.1590/S0100-40422 009000100032

Grune T, Reinheckel T, Davies KJ (1997) Degradation of oxidized proteins in mammalian cells. FASEB J 11:526-534. https://doi. org/10.1096/fasebj.11.7.9212076

Harman D (2006) Free radical theory of aging: an update. Ann N Y Acad Sci 1067:10-21. https://doi.org/10.1196/annals.1354.003

Hayat S, Hayat Q, Alyemeni MN, Wani AS et al (2012) Role of proline under changing environments: a review. Plant Signal Behav 7:1456-1466. https://doi.org/10.4161/psb.21949

Hu D, Ma G, Wang Q et al (2012a) Spatial and temporal nature of reactive oxygen species production and programmed cell death in elm (Ulmus pumila L.) seeds during controlled deterioration. Plant Cell Environ 35:2045-2059
Hu J, Baker A, Bartel B et al (2012b) Plant peroxisomes: biogenesis and function. Plant Cell 24:2279-2303. https://doi.org/10.111 1/j.1365-3040.2012.02535.x

Huang H, Ullah F, Zhou DX, Yi M, Zhao Y (2019) Mechanisms of ROS regulation of plant development and stress responses. Front Plant Sci. https://doi.org/10.3389/fpls.2019.00800

Ighodaro OM, Akinloye OA (2017) First line defence antioxidantssuperoxide dismutase (SOD), catalase (CAT) and glutathione peroxidase (GPX): their fundamental role in the entire antioxidant defence grid. Alexandria J Med 54:287-293. https://doi. org/10.1016/j.ajme.2017.09.001

Jeevan Kumar SP, Rajendra Prasad S, Banerjee R, Thammineni C (2015) Seed birth to death: dual functions of reactive oxygen species in seed physiology. Ann Bot 116:663-668. https://doi. org/10.1093/aob/mcv098

Jiménez-Alfaro B, Silveira FA, Fidelis A et al (2016) Seed germination traits can contribute better to plant community ecology. J Veg Sci 27:637-645. https://doi.org/10.1111/jvs.12375

Jones N (2017) How the world passed a carbon threshold and why it matters. Yale Environ 360

Kalemba EM, Pukacka S (2014) Carbonylated proteins accumulated as vitality decreases during long-term storage of beech (Fagus sylvatica L.) seeds. Trees 28:503-515. https://doi.org/10.1007/ s00468-013-0967-9

Kibinza S, Bazin J, Bailly C et al (2011) Catalase is a key enzyme in seed recovery from ageing during priming. Plant Sci 181:309315. https://doi.org/10.1016/j.plantsci.2011.06.003

Kijowska-Oberc J, Staszak AM, Kamiński J, Ratajczak E (2020) Adaptations of forest trees to rapidly changing climate. Forests 11:123. https://doi.org/10.3390/f11020123

Kim DH, Han SH (2018) Seed coat and aging conditions affect germination and physiological changes of aging Korean pine seeds. J For Res 23:372-379. https://doi.org/10.1080/13416 979.2018.1531478

Koenig WD, Alejano R, Carbonero MD et al (2016) Is the relationship between mast-seeding and weather in oaks related to their life-history or phylogeny? Ecology 97:2603-2615. https://doi. org/10.1002/ecy.1490

Kranner I, Birtić S, Anderson KM, Pritchard HW (2006) Glutathione half-cell reduction potential: a universal stress marker and modulator of programmed cell death? Free Radic Biol Med 40:21552165. https://doi.org/10.1016/j.freeradbiomed.2006.02.013

Kristensen BK, Askerlund P, Bykova NV et al (2004) Identification of oxidised proteins in the matrix of rice leaf mitochondria by immunoprecipitation and two-dimensional liquid chromatography-tandem mass spectrometry. Phytochemistry 65:1839-1851. https://doi.org/10.1016/j.phytochem.2004.04.007

Kumar V, Shriram V, Hossain MA, Kishor PK (2015) Engineering proline metabolism for enhanced plant salt stress tolerance. In: Wani SH, Hussain MA (eds) Managing salinity tolerance in plants: molecular and genomic perspectives, pp.349

Kubala S, Wojtyla $€$, Quinet M, Lechowska K, Lutts S, Garnczarska M (2015) Enhanced expression of the proline synthesis gene P5CSA in relation to seed osmopriming improvement of Brassica napus germination under salinity stress. J Plant Physiol 183:1-12. https ://doi.org/10.1016/j.jplph.2015.04.009

Kurek K, Plitta-Michalak B, Ratajczak E (2019) Reactive oxygen species as potential drivers of the seed aging process. Plants (Basel). https://doi.org/10.3390/plants8060174

Lehner A, Mamadou N, Poels P et al (2008) Changes in soluble carbohydrates, lipid peroxidation and antioxidant enzyme activities in the embryo during ageing in wheat grains. J Cereal Sci 47:555-565. https://doi.org/10.1016/j.jcs.2007.06.017

Leprince O, Buitink J, Hoekstra FA (1999) Axes and cotyledons of recalcitrant seeds of Castanea sativa Mill. exhibit contrasting 
responses of respiration to drying in relation to desiccation sensitivity. J Exp Bot 50:1515-1524. https://doi.org/10.1093/ jxb/50.338.1515

Li Y, Wang Y, Xue H et al (2017) Changes in the mitochondrial protein profile due to ROS eruption during ageing of elm (Ulmus pumila L.) seeds. Plant Physiol Biochem 114:72-87. https:// doi.org/10.1016/j.plaphy.2017.02.023

Liberatore KL, Dukowic-Schulze S, Miller ME et al (2016) The role of mitochondria in plant development and stress tolerance. Free Radic Biol Med 100:238-256. https://doi.org/10.1016/j.freer adbiomed.2016.03.033

Liebthal M, Maynard D, Dietz KJ (2018) Peroxiredoxins and redox signaling in plants. Antioxid Redox Signal 28(7):609-624. https://doi.org/10.1089/ars.2017.7164

Luis A, Sandalio LM, Corpas FJ et al (2006) Reactive oxygen species and reactive nitrogen species in peroxisomes. Production, scavenging, and role in cell signaling. Plant Physiol 141:330-335. https://doi.org/10.1104/pp.106.078204

Marnett LJ (1999) Lipid peroxidation-DNA damage by malondialdehyde. Mutat Res Fundam Mol Mech Mutagenesis 424(1-2):8395. https://doi.org/10.1016/S0027-5107(99)00010-X

Mittler R, Vanderauwera S, Gollery M, Van Breusegem F (2004) Reactive oxygen gene network of plants. Trends Plant Sci 9:490-498. https://doi.org/10.1016/j.tplants.2004.08.009

Møller IM, Kristensen BK (2004) Protein oxidation in plant mitochondria as a stress indicator. Photochem Photobiol Sci 3:730735. https://doi.org/10.1039/B315561G

Monks A, Monks JM, Tanentzap AJ (2016) Resource limitation underlying multiple masting models makes mast seeding sensitive to future climate change. New Phytol 210:419-430. https ://doi.org/10.1111/nph.13817

Morin X, Viner D, Chuine I (2008) Tree species range shifts at a continental scale: new predictive insights from a processbased model. J Ecol 96:784-794. https://doi.org/10.111 1/j.1365-2745.2008.01369.x

Murphy MP (2009) How mitochondria produce reactive oxygen species. Biochem J 417(1):1-13. https://doi.org/10.1042/BJ200 81386

Nietzel T, Mostert J, Ruberti C, Née G, Fuchs P, Wagner S et al (2020) Redox-mediated kick-start of mitochondrial energy metabolism drives resource-efficient seed germination. Proc Natl Acad Sci 117(1):741-751. https://doi.org/10.1073/ pnas. 1910501117

Nishimura M, Hayashi M, Kato A et al (1996) Functional transformation of microbodies in higher plant cells. Cell Struct Funct 21:387-393. https://doi.org/10.1247/csf.21.387

Noctor G, Reichheld J-P, Foyer CH (2018) ROS-related redox regulation and signaling in plants. Semin Cell Dev Biol 80:3-12. https://doi.org/10.1016/j.semcdb.2017.07.013

Oliver MJ, Tuba Z, Mishler BD (2000) The evolution of vegetative desiccation tolerance in land plants. Plant Ecol 151:85-100. https://doi.org/10.1023/A:1026550808557

Palma JM, Sandalio LM, Corpas FJ et al (2002) Plant proteases, protein degradation, and oxidative stress: role of peroxisomes. Plant Physiol Biochem 40:521-530. https://doi.org/10.1016/ S0981-9428(02)01404-3

Parkhey S, Naithani SC, Keshavkant S (2012) ROS production and lipid catabolism in desiccating Shorea robusta seeds during aging. Plant Physiol Biochem 57:261-267. https://doi. org/10.1016/j.plaphy.2012.06.008

Pearse IS, Koenig WD, Kelly D (2016) Mechanisms of mast seeding: resources, weather, cues, and selection. New Phytol 212:546562. https://doi.org/10.1111/nph.14114

Pritchard HW, Daws MI, Fletcher BJ et al (2004) Ecological correlates of seed desiccation tolerance in tropical African dryland trees. Am J Bot 91:863-870. https://doi.org/10.3732/ajb.91.6.863
Pukacka S, Ratajczak E (2007) Age-related biochemical changes during storage of beech (Fagus sylvatica L.) seeds. Seed Sci Res 17:45-53. https://doi.org/10.1017/S0960258507629432

Pukacka S, Hoffmann SK, Goslar J et al (2003) Water and lipid relations in beech (Fagus sylvatica $\mathrm{L}$.) seeds and its effect on storage behaviour. BBA Gen Subj 1621:48-56. https://doi.org/10.1016/ S0304-4165(03)00046-1

Pyngrope S, Bhoomika K, Dubey RS (2013) Oxidative stress, protein carbonylation, proteolysis and antioxidative defense system as a model for depicting water deficit tolerance in Indica rice seedlings. Plant Growth Regul 69:149-165. https://doi.org/10.1007/ s10725-012-9758-3

Rajjou L, Lovigny Y, Groot SPC, Belghazi M, Job C, Job D (2008) Proteome-wide characterization of seed aging in Arabidopsis: a comparison between artificial and natural aging protocols. Plant Physiol. https://doi.org/10.1104/pp.108.123141

Ratajczak E, Małecka A, Bagniewska-Zadworna A, Kalemba EM (2015) The production, localization and spreading of reactive oxygen species contributes to the low vitality of long-term stored common beech (Fagus sylvatica L.) seeds. J Plant Physiol 174:147-156. https://doi.org/10.1016/j.jplph.2014.08.021

Ratajczak E, Dietz KJ, Kalemba EM (2019a) The occurrence of peroxiredoxins and changes in redox state in Acer platanoides and Acer pseudoplatanus during seed development. J Plant Growth Regul 38(1):298-314. https://doi.org/10.1007/s00344-018-9841-8

Ratajczak E, Małecka A, Ciereszko I, Staszak AM (2019b) Mitochondria are important determinants of the aging of seeds. Int J Mol Sci 20:1568. https://doi.org/10.3390/ijms20071568

Ratajczak E, Staszak AM, Wojciechowska N, Bagniewska-Zadworna A, Dietz KJ (2019c) Regulation of thiol metabolism as a factor that influences the development and storage capacity of beech seeds. J Plant Physiol 239:61-70. https://doi.org/10.1016/j.jplph 2019.06.002

Robb EL, Hall AR, Prime TA, Eaton S, Szibor M, Viscomi C et al (2018) Control of mitochondrial superoxide production by reverse electron transport at complex I. J Biol Chem 293(25):9869-9879

Rouhier N, Jacquot J-P (2005) The plant multigenic family of thiol peroxidases. Free Radic Biol Med 38:1413-1421. https://doi. org/10.1016/j.freeradbiomed.2004.07.037

Sano N, Rajjou L, North HM, Debeaujon I, Marion-Poll A, Seo M (2016) Staying alive: molecular aspects of seed longevity. Plant Cell Physiol 57:660-667. https://doi.org/10.1093/pcp/pcv186

Selinski J, Scheibe R, Day DA, Whelan J (2018) Alternative oxidase is positive for plant performance. Trends Plant Sci 23:588-597. https://doi.org/10.1016/j.tplants.2018.03.012

Sershen N, Perumal A, Varghese B, Govender P, Ramdhani S, Berjak P (2014) Effects of elevated temperatures on germination and subsequent seedling vigour in recalcitrant Trichiliaemetica seeds. $\mathrm{S}$ Afr J Bot 90:153-162. https://doi.org/10.1016/j.sajb.2013.11.005

Sharma P, Jha AB, Dubey RS, Pessarakli M (2012) Reactive oxygen species, oxidative damage, and antioxidative defense mechanism in plants under stressful conditions. J Bot. https://doi. org/10.1155/2012/217037

Silva LJD, Dias DCFDS, Sekita MC, Finger FL (2018) Lipid peroxidation and antioxidant enzymes of Jatropha curcas $\mathrm{L}$. seeds stored at different maturity stages. Acta Scientiarum Agron. https://doi. org/10.4025/actasciagron.v40i1.34978

Siripornadulsil S, Traina S, Verma DPS et al (2002) Molecular mechanisms of proline-mediated tolerance to toxic heavy metals in transgenic microalgae. Plant Cell 14:2837-2847. https://doi. org/10.1105/tpc.004853

Solarik KA, Messier C, Ouimet R, Bergeron Y, Gravel D (2018) Local adaptation of trees at the range margins impacts range shifts in the face of climate change. Glob Ecol Biogeogr 27(12):15071519. https://doi.org/10.1111/geb.12829 
St Clair SB, Lynch JP (2005) Base cation stimulation of mycorrhization and photosynthesis of sugar maple on acid soils are coupled by foliar nutrient dynamics. New Phytol. https://doi.org/10.111 1/j.1469-8137.2004.01249.x

Starkov AA, Fiskum G, Chinopoulos C et al (2004) Mitochondrial $\alpha$-ketoglutarate dehydrogenase complex generates reactive oxygen species. J Neurosci 24:7779-7788. https://doi.org/10.1523/ JNEUROSCI.1899-04.2004

Walters C (2015) Orthodoxy, recalcitrance and in-between: describing variation in seed storage characteristics using threshold responses to water loss. Planta 242:397-406

Walters C, Wheeler LM, Grotenhuis JM (2005) Longevity of seeds stored in a genebank: species characteristics. Seed Sci Res 15:120. https://doi.org/10.1079/SSR2004195

Wang Y, Branicky R, Noë A, Hekimi S (2018) Superoxide dismutases: dual roles in controlling ROS damage and regulating ROS signalling. J Cell Biol 217(6):1915-1928. https://doi.org/10.1083/ jcb.201708007

Wang WJ, Thompson FR III, He HS, Fraser JS, Dijak WD, Jones-Farrand $T$ (2019) Climate change and tree harvest interact to affect future tree species distribution changes. J Ecol 107(4):19011917. https://doi.org/10.1111/1365-2745.13144

Waterworth WM, Bray CM, West CE (2015) The importance of safeguarding genome integrity in germination and seed longevity. $\mathrm{J}$ Exp Bot 66:3549-3558. https://doi.org/10.1093/jxb/erv080
Willis CG, Ruhfel B, Primack RB et al (2008) Phylogenetic patterns of species loss in Thoreau's woods are driven by climate change. PNAS 105:17029-17033. https://doi.org/10.1073/pnas.08064 46105

Winger AM, Taylor NL, Heazlewood JL et al (2007) The cytotoxic lipid peroxidation product 4-hydroxy-2-nonenal covalently modifies a selective range of proteins linked to respiratory function in plant mitochondria. J Biol Chem 282:37436-37447. https://doi. org/10.1074/jbc.M702385200

Xia F, Wang X, Li M, Mao P (2015) Mitochondrial structural and antioxidant system responses to aging in oat (Avena sativa $\mathrm{L}$.) seeds with different moisture contents. Plant Physiol Biochem 94:122-129. https://doi.org/10.1016/j.plaphy.2015.06.002

Xie X, He Z, Chen N, Tang Z, Wang Q, Cai Y (2019) The roles of environmental factors in regulation of oxidative stress in plant. Biomed Res Int. https://doi.org/10.1155/2019/9732325

Yin G, Whelan J, Wu S et al (2016) Comprehensive mitochondrial metabolic shift during the critical node of seed ageing in rice. PLoS One 11:e0148013. https://doi.org/10.1371/journal.pone.0148013

Publisher's Note Springer Nature remains neutral with regard to jurisdictional claims in published maps and institutional affiliations. 